\section{Differential Influences of Leaf Tip Trimming on Light Interception and Dry Matter Production in Tomato Dutch Cultivar Gourmet and Japanese Cultivar Momotaro York}

\author{
Tadahisa Higashide', Yuya Mochizuki, Takeshi Saito, \\ Yasushi Kawasaki, Dong-Hyuk Ahn, and Akio Ohyama \\ NARO Institute of Vegetable and Floriculture Science, National Agriculture \\ and Food Research Organization, Tsukuba, Ibaraki 305-8519, Japan
}

Additional index words. Solanum lycopersicum, crop canopy, light-extinction coefficient, light-use efficiency, yield

\begin{abstract}
To investigate the influence of morphological changes in individual leaves of tomato on light interception and dry matter (DM) production, we altered leaf shape by trimming leaflets of young or mature leaves of the Dutch cultivar Gourmet and the Japanese cultivar Momotaro York. Young leaves 5-cm long were trimmed of their first and second leaflets from the leaf apex. Mature leaves were similarly trimmed at $\geq 71$ days after transplanting (DAT). The individual leaf area (LA) of intact 'Momotaro York' leaves was significantly larger than that of 'Gourmet'. Light-photosynthesis curves of the cultivars were almost identical. Mature-trimmed plants of both cultivars had a smaller individual LA and a smaller leaf area index (LAI), and a greater light-extinction coefficient (LEC). Although there was no significant difference in light-use efficiency (LUE) (i.e., DM production per unit intercepted solar radiation) in 'Gourmet' between trimming stages, LUE of 'Momotaro York' was decreased significantly by young-leaf trimming. Trimming of young leaves significantly decreased the LEC in 'Gourmet' but increased it in 'Momotaro York'. Although leaf trimming would be impractical for commercial cultivation, these results may provide with a clue for breeding for yield improvement.
\end{abstract}

Yields of greenhouse tomatoes (Solanum lycopersicum L.) in the Netherlands have doubled over the past 30 years (KIG, 2005), whereas those in Japan have not increased since the 1980s, remaining much less than $\approx 30 \mathrm{~kg} \cdot \mathrm{m}^{-2}$ per year. Although the yield difference could be determined by many factors, including climate, greenhouse light transmissivity, and equipment, a crucial factor in the Netherlands is breeding for high yield. The yield of Dutch cultivars by year of release increased by $\approx 0.9 \%$ per year from 1950 to 2000 (Higashide and Heuvelink, 2009). However, high-yielding cultivars have not been a priority for Japanese tomato breeding in the past 80 years. The higher soluble solids content for a given DM content in fruits of several modern cultivars than in

\footnotetext{
Received for publication 23 Nov. 2016. Accepted for publication 2 Apr. 2017.

This work was partly supported by the Council for Science, Technology and Innovation, the CrossMinisterial Strategic Innovation Promotion Program's "Technologies for creating next-generation agriculture, forestry and fisheries," and the Ministry of Agriculture, Forestry and Fisheries' "Revolutionary Technology Development/Urgent Project (Regional Strategy: Next-Generation Horticulture Development)."

${ }^{1}$ Corresponding author. E-mail: ton@affrc.go.jp.
}

older cultivars (Higashide et al., 2012) indicates that Japanese breeders have focused on fruit qualities such as shape, color, and soluble solids rather than yield. To improve yields in Japan, the introduction of highyielding Dutch cultivars could be effective. However, because Japanese consumers and retailers insist on flavor more than yield, they would reject the introduction of such Dutch cultivars. Hence, Japanese growers must try to improve yields by using current Japanese cultivars until releasing a cultivar that provides both high yield and fruit quality. Although grafting onto Dutch rootstock improved fruit yield and LUE of a current Japanese cultivar (Higashide et al., 2014), and $\mathrm{CO}_{2}$ enrichment also improved the yield of current Japanese cultivars (Higashide et al., 2015; Kuroyanagi et al., 2014; Yasuba et al., 2011), yield improvement remains inadequate in Japan.

DM production is an important factor in fruit yield and is determined, in part, by light interception by the crop canopy, which determines the photosynthetic rate of the canopy. Recently developed greenhouse covers increase diffuse light and decrease direct light. Diffuse light improves light distribution and the photosynthetic rate of the crop canopy, and thus improves yield (Li et al., 2014; Li and Yang, 2015). However, light distribution in the crop canopy is determined mainly by species and cultivars rather than greenhouse covers. Light penetration in a crop canopy can be represented by the LEC, i.e., light attenuation rate against increase in LA. In Dutch cultivars, the LEC in the canopy decreased significantly with the year of release, whereas yield and DM production increased (Higashide and Heuvelink, 2009). Although the leaves of Dutch cultivars face upward and those of Japanese cultivars hang downward (Nakano et al., 2012), this difference in leaf angle cannot be related to the LEC, as the coefficient of Japanese cultivars can be lower or higher than that of Dutch cultivars (Higashide and Heuvelink, 2009; Higashide et al., 2014). Modern Japanese cultivars also have lower LECs than earlier cultivars, but without higher yields, so a low coefficient is not related to high DM production (Higashide et al., 2012, 2015).

The LEC is influenced by individual leaf shape and angle, as well as by the distribution of leaves within the canopy. In general, if the leaf angle tends toward the vertical, the coefficient decreases as more light penetrates the canopy. In contrast, if it tends toward the horizontal, the coefficient increases as less light reaches the lower canopy. Goudriaan (1988) reported the effects of LAI and solar radiation angle on the LEC of plants with different leaf angle distributions. Iwakiri and Inayama (1974) reported that leaf angles of cucumber plants were more horizontal in the lower part of the canopy and were more vertical in the upper part. However, Acock et al. (1978) reported that the coefficient was higher in the upper part of a tomato plant canopy (0.63) than in the lower part (0.52); thus, light transmission was higher in the lower part. Papadopoulos and Pararajasingham (1997) reviewed the effects of tomato plant spacing on light interception and photosynthetic rate.

Leaf shape could also relate to light interception by the plant canopy because the lacinia of leaves contribute directly to individual LA, and leaf length indirectly affects leaf angle because long and heavier leaves are more likely to bend downward under their own weights. Molecular biological investigations of the leaf shape of tomato have revealed the mechanisms of leaf formation and important genes such as KNOTTED1like homeodomain $(K N O X)$ (Kim et al., 2003). However, there is no information on the effects of individual leaf shape on light interception, DM production, and thus yield. Clarification of the effect of leaf shape on light interception and DM production will be useful for yield improvement through breeding and the development of growing techniques. Here, we focused on individual leaf shape and light interception by the plant canopy in Dutch and Japanese cultivars with different leaf shapes but the same photosynthetic rate of individual leaves (Higashide et al., 2014). We altered the leaf shape by trimming leaves before or after they had expanded and investigated the effects of this 
morphological change on light interception characteristics and DM production.

\section{Materials and Methods}

We compared the Dutch tomato cultivar Gourmet (De Ruiter Seeds, Bergschenhoek, the Netherlands) and the Japanese cultivar Momotaro York (Takii Seed, Kyoto, Japan), which have almost the same leaf photosynthetic rate (Higashide et al., 2014). Seeds were sown in seed trays on 28 July 2009 , and seedlings were transplanted into rockwool cubes 20 d later. On 25 Aug. 2009, seedlings were transplanted into seven rows (60 plants per row, 2.5 plants $/ \mathrm{m}^{2}$ ) in a rockwool system in a greenhouse compartment $(13.2 \times 13.5 \mathrm{~m})$ at the National Agriculture and Food Research Organization's Institute of Vegetable and Tea Science in Taketoyo, Japan. Ventilation began at $23{ }^{\circ} \mathrm{C}$, and heating began at $12{ }^{\circ} \mathrm{C}$. The experiment ended on $11 \mathrm{Dec}$. 2009.

All plants received Otsuka-SA nutrient solution (17.5 $\mathrm{mM} \mathrm{NO}_{3}^{-}, 10.2 \mathrm{mM} \mathrm{K}^{+}, 8.2 \mathrm{~mm}$ $\mathrm{Ca}^{2+}, 3.0 \mathrm{~mm} \mathrm{Mg}{ }^{2+}, 4.4 \mathrm{~mm} \mathrm{H}_{2} \mathrm{PO}_{4}^{-}, 2.7$ $\mathrm{mg} \cdot \mathrm{L}^{-1} \mathrm{Fe}, 1.2 \mathrm{mg} \cdot \mathrm{L}^{-1} \mathrm{Mn}, 0.51 \mathrm{mg} \cdot \mathrm{L}^{-1} \mathrm{~B}$, $0.09 \mathrm{mg} \cdot \mathrm{L}^{-1} \mathrm{Zn}, 0.03 \mathrm{mg} \cdot \mathrm{L}^{-1} \mathrm{Cu}$, and 0.03 $\mathrm{mg} \cdot \mathrm{L}^{-1} \mathrm{Mo}$; Otsuka Agri-Techno, Tokyo, Japan) with the electrical conductivity adjusted to $1.2 \mathrm{dS} \cdot \mathrm{m}^{-1}$ at transplanting and increased every week by $0.3 \mathrm{dS} \cdot \mathrm{m}^{-1}$ up to $2.5 \mathrm{dS} \cdot \mathrm{m}^{-1} ; \mathrm{pH}$ was adjusted to $6.0-7.0$. The solution was supplied at a rate based on outdoor solar radiation (Yasuba et al., 2013). Between $20 \%$ and $30 \%$ of the total daily supply of the solution was drained and discarded. Flowers were pollinated by an electric vibrator on the lowest three trusses and by bumble bees (Bombus terrestris) on the fourth truss onward. Plants were trained, and leaves were pruned according to the current standard Dutch practices, but the number of fruit per truss was not altered. All plants were pinched at the height of the top of the training wire $(\approx 300 \mathrm{~cm}$ aboveground) above the 10th to 12th truss on 2 Nov. 2009. Air temperature, relative humidity, and solar radiation inside and outside the greenhouse were measured at 1-min intervals by a ubiquitous environmental control system (Yasuba et al., 2013).

The experiment was conducted in three blocks in a randomized complete block design. Each block contained two double rows, and the three blocks were guarded by a border row of 30 plants on each side. The spacing was $60 \mathrm{~cm}$ between adjacent rows and $190 \mathrm{~cm}$ between adjacent double rows, with 20 plants per leaf treatment per cultivar per block (three treatments per double row). The border plants were excluded from the measurement.

To test the effects of leaf shape, we compared plants with intact leaves with plants whose leaves were trimmed while young or when mature (Fig. 1). In the control treatment, we left plants untrimmed. In the young-leaf treatment, when each leaf had reached $\approx 5 \mathrm{~cm}$ length, we trimmed the first and second leaflets counting from the apex of

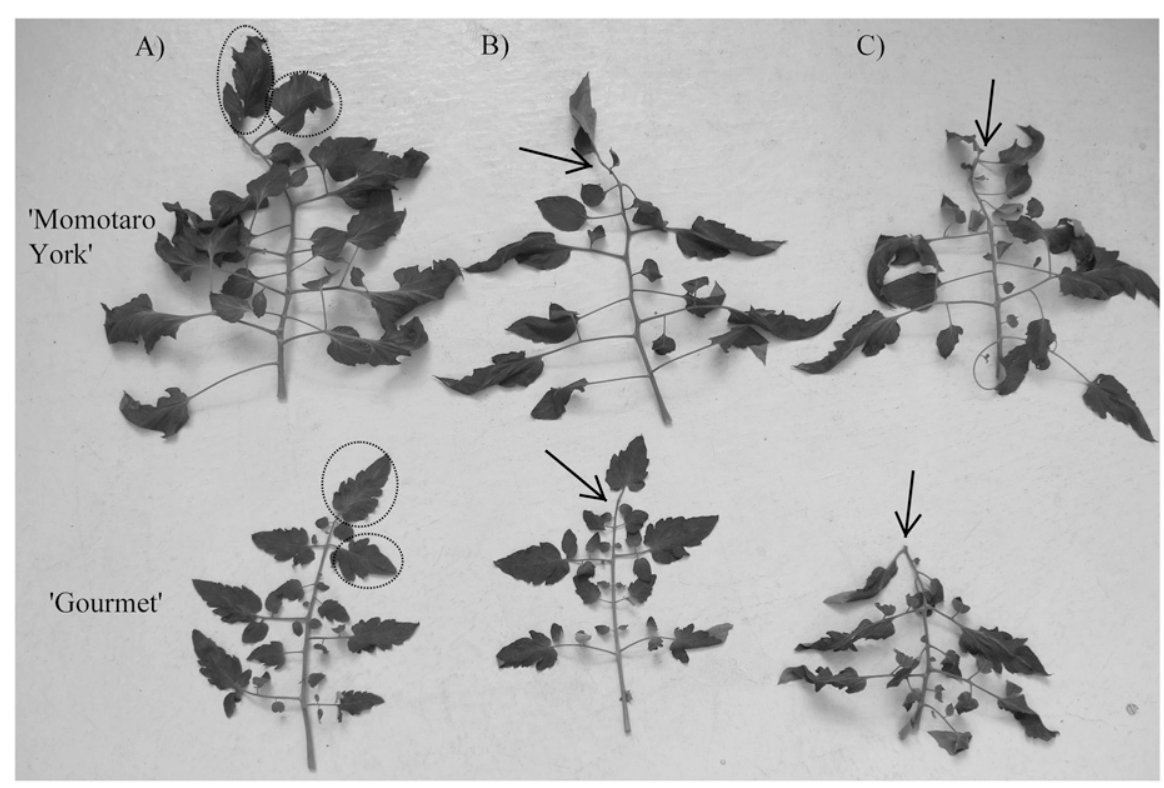

Fig. 1. Alteration of tomato leaf shape in Dutch cultivar Gourmet and Japanese cultivar Momotaro York at the end of the experiment. (A) No trimming; (B) trimming of young leaf; (C) trimming of mature leaf. Arrows show the site of trimming. First and second leaflets counting from the apex of each leaf were trimmed.

each leaf, two or three times a week. In the mature-leaf treatment, we similarly trimmed fully expanded leaves at $\geq 71$ DAT; the plants reached at the top of the training wire. All leaves were trimmed.

We harvested all mature fruit from six to eight plants per treatment per cultivar in each block, two or three times a week for 8 weeks, and measured fruit fresh weight (FW) and dry weight (DW). We measured leaf (blade + petiole) area with an LI-3100C leaf area meter (LI-COR, Lincoln, NE). We also measured the FW and DW of leaves, stems, and all fruits (mature and immature fruits, separately) of two or four plants destructively sampled per treatment per cultivar in each block at $0,23,56$, and 107 DAT. The fraction of DM distributed to fruit was calculated as the total DW of fruit divided by total dry matter production (TDM). To avoid the effects of this sampling on the remaining plants and on light interception, we sampled two plants and remained two adjacent guard plants in the second and third destructive samplings.

At 42 DAT, between $1100 \mathrm{HR}$ and $1430 \mathrm{HR}$, we selected two unshaded mature leaves (third to fifth from the top) from each of two plants per cultivar per block and measured the maximum individual leaf photosynthetic rate with a portable photosynthesis system (LI-6400; LI-COR) at a photosynthetic photon flux density (PPFD) of $1500 \mu \mathrm{mol} \cdot \mathrm{m}^{-2} \cdot \mathrm{s}^{-1}$ and a $\mathrm{CO}_{2}$ concentration of $1000 \mu \mathrm{mol} \cdot \mathrm{mol}^{-1}$. To obtain a photosynthetic light-response curve for each cultivar, we measured the photosynthetic rate of a single upper mature leaf per cultivar two or four times at 51 DAT at a PPFD of $0,10,20,40,60,200,300,500$, 1000 , and $1500 \mu \mathrm{mol} \cdot \mathrm{m}^{-2} \cdot \mathrm{s}^{-1}$ and $\mathrm{a}^{\mathrm{CO}_{2}}$ concentration of $380 \mu \mathrm{mol} \cdot \mathrm{mol}^{-1}$. From the relation between PPFD and photosynthetic rate, we approximated photosynthetic curves with a nonrectangular hyperbolic curve:

$P=\left(\varphi \cdot I+P_{\mathrm{M}}-\left\{\left(\varphi \cdot I+\mathrm{P}_{\mathrm{M}}\right)^{2}-4 \varphi \cdot I \cdot \theta \cdot P_{\mathrm{M}}\right\}^{0.5}\right) / 2 \theta-\mathrm{R}$

where $P=$ photosynthetic rate, $\varphi=$ initial slope, $I=$ light intensity, $P_{\mathrm{M}}=$ maximum photosynthetic rate, $\theta=$ degree of curvature, and $R=$ respiration rate (Thornley, 1976).

To obtain the LEC within the plant canopy of each treatment, we measured PPFD with a 1-m-long PPFD sensor (LI-191SA; LI-COR) at six different heights within the closed canopies at 63 and 72 DAT, and above the canopy (LI-190SA; LI-COR), and recorded it on a datalogger (GL200; Graphtec, Yokohama, Japan). The individual LA of each treatment was obtained using the following regression equation:

$$
A_{1}=a \cdot L_{1} \cdot W_{1}
$$

where $A_{1}$ represents the LA (square centimeters), $a$ represents a proportionality factor for each cultivar and treatments $(0.31$, 'Gourmet', young-trimmed; 0.34, 'Gourmet', mature-trimmed; 0.33, 'Gourmet', untrimmed; 0.26, 'Momotaro York', young-trimmed; 0.29, 'Momotaro York', mature-trimmed; 0.28, 'Momotaro York', untrimmed), $L_{1}$ represents the leaf length (centimeters), and $W_{1}$ represents the leaf width (centimeters). Each $a$ was obtained by each regression equation $\left(R^{2}=\right.$ 0.69 to $0.73, P<0.001$ for all regressions) by destructive sampling at 56 DAT. The cumulative LAI at each of the six heights within the canopy was calculated from the individual LA and the number of leaves between that height and the one above it. The LEC was calculated as the slope of a logarithmic regression of PPFD against cumulative LAI at the six heights using the following equation (Monsi and Saeki, 2005): 


$$
I=I_{0} \cdot e^{-k \cdot L}
$$

where $I\left(\mathrm{MJ} \cdot \mathrm{m}^{-2}\right)$ represents the light intensity at a given point in the plant canopy, $I_{0}$ $\left(\mathrm{MJ} \cdot \mathrm{m}^{-2}\right)$ represents the light intensity above the canopy, $k$ represents the LEC, and $L$ represents the cumulative LAI $\left(\mathrm{m}^{2} \cdot \mathrm{m}^{-2}\right)$ at that point in the canopy. In general, large $k$ indicates that upper leaves intercept a large amount of irradiated light and lower leaves intercept relatively little. Conversely, the middle and lower leaves in a small $k$ canopy partially intercept irradiated light. In the preliminary experiment, we measured leaf angles from horizontal plane by a slant rule (SR-90; Akatsuki MFG, Kyoto, Japan) at several positions in canopies of 'Gourmet' and 'Momotaro Fight', sister cultivar of 'Momotaro York'. However, we did not measure the angles in this experiment because the angles differed among leaves and the leaf position even in the same cultivar.

LUE was calculated as the slope of the linear regression of the cumulative TDM against the integrated photosynthetically active radiation $(P A R)$ intercepted on the four sampling dates: 0, 23, 56, and 107 DAT. Daily PAR intercepted by plants was calculated from LAI and the corresponding LEC in each treatment by the following equation:

$$
I L=\left(1-\mathrm{e}^{-k \cdot L}\right) \cdot R
$$

where $I L$ represents the daily $P A R$ intercepted by plants and $R$ represents daily cumulative $P A R$. Greenhouse transmissivity and the fraction of $P A R$ were assumed to be $60 \%$ and $50 \%$ of global radiation, respectively.

The effects of the three leaf treatments, two cultivars, and their interaction on the growth characteristics were analyzed by twoway analysis of variance (ANOVA). Pearson's correlations among the leaf and growth characteristics were also investigated as described by Higashide and Heuvelink (2009).

\section{Results}

Morphology and photosynthetic rate in individual leaves. After the trimming of the younger leaves, the third leaflet elongated toward the tip, and the whole leaf morphology came to resemble intact leaves at maturity except for the number of leaflets (Fig. 1B). In contrast, the morphology of mature leaves did not adapt (Fig. 1C). At 56 DAT, leaves of 'Momotaro York' were significantly longer than those of 'Gourmet' (Table 1). Youngtrimmed leaves were significantly shorter than untrimmed leaves. There was no significant interaction of cultivars $\times$ leaf trimming for leaf length at 56 DAT. At 71 DAT, however, there was significant interaction of cultivars $\times$ leaf trimming. There was no significant difference in length between untrimmed and youngtrimmed leaves in either cultivar. In contrast, mature-trimming significantly decreased leaf length in each cultivar. At both 56 and 71 DAT, leaves of 'Momotaro York' were significantly wider than those of 'Gourmet'. Leaf widths did not differ significantly among leaf

Table 1. Effects of leaf trimming on individual leaf length, width, and area in tomato Dutch cultivar

\begin{tabular}{|c|c|c|c|c|c|c|c|}
\hline \multirow[b]{2}{*}{ Cultivar } & \multirow[b]{2}{*}{ Leaf trimming } & \multicolumn{2}{|c|}{$\begin{array}{c}\text { Leaf } \\
\text { length } \\
(\mathrm{cm} / \text { leaf })\end{array}$} & \multicolumn{2}{|c|}{$\begin{array}{c}\text { Leaf } \\
\text { width } \\
(\mathrm{cm} / \text { leaf })\end{array}$} & \multicolumn{2}{|c|}{$\begin{array}{l}\text { Individual } \\
\text { leaf area } \\
\left(\mathrm{cm}^{2} / \mathrm{leaf}\right)\end{array}$} \\
\hline & & $56 \mathrm{DAT}^{\mathrm{z}}$ & $71 \mathrm{DAT}^{\mathrm{y}}$ & $56 \mathrm{DAT}$ & $71 \mathrm{DAT}$ & $56 \mathrm{DAT}$ & $71 \mathrm{DAT}$ \\
\hline Gourmet & Untrimmed & 42 & $37 a^{x}$ & 45 & 37 & 655 & $553 \mathrm{~b}$ \\
\hline Gourmet & Young-trimmed & 40 & $35 \mathrm{a}$ & 47 & 39 & 606 & $458 \mathrm{~b}$ \\
\hline Gourmet & Mature-trimmed & - & $23 \mathrm{c}$ & - & 40 & - & $325 \mathrm{~d}$ \\
\hline Momotaro York & Untrimmed & 54 & $49 \mathrm{a}$ & 53 & 47 & 834 & $724 \mathrm{a}$ \\
\hline Momotaro York & Young-trimmed & 49 & $44 \mathrm{a}$ & 54 & 47 & 688 & $581 \mathrm{ab}$ \\
\hline Momotaro York & Mature-trimmed & - & $26 \mathrm{~b}$ & - & 47 & - & $375 \mathrm{c}$ \\
\hline \multirow[t]{3}{*}{ Significance $^{\mathrm{w}}$} & Cultivar & $* * *$ & $* * *$ & $* * *$ & $* * *$ & $* * *$ & $* * *$ \\
\hline & Leaf trimming & $* * *$ & $* * *$ & NS & NS & $* *$ & $* * *$ \\
\hline & Interaction & NS & $* * *$ & NS & NS & NS & $* *$ \\
\hline
\end{tabular}
Gourmet and Japanese cultivar Momotaro York at 56 and $71 \mathrm{~d}$ after tomato transplanting (DAT).

${ }^{\mathrm{z}}$ Mature leaves only $(n=24-44)$.

${ }^{\mathrm{y}}$ Including young leaves $(n=50-380)$.

${ }^{\mathrm{x}}$ Different letters indicate significant differences at $P<0.05$ by analysis of variance (ANOVA) followed Dunn's multiple comparison test.

${ }^{\mathrm{w}} \mathrm{NS}, * *, * * *$ Nonsignificant or significant at $P<0.01$ or 0.001 , respectively, by ANOVA.

Table 2. Effects of leaf trimming on the maximum photosynthetic rate and light-extinction coefficients in

\begin{tabular}{|c|c|c|c|c|}
\hline \multirow[b]{2}{*}{ Cultivar } & \multirow[b]{2}{*}{ Leaf trimming } & \multirow{2}{*}{$\begin{array}{c}\text { Photosynthetic } \\
\operatorname{rate}^{\mathrm{z}}\left(\mu \mathrm{mol} \cdot \mathrm{m}^{-2} \cdot \mathrm{s}^{-1}\right)\end{array}$} & \multicolumn{2}{|c|}{$\begin{array}{l}\text { Light-extinction } \\
\text { coefficient }\end{array}$} \\
\hline & & & $63 \mathrm{DAT}$ & $72 \mathrm{DAT}$ \\
\hline Gourmet & Untrimmed & 27.6 & $0.82 \mathrm{~b}^{\mathrm{y}}$ & $1.07 \mathrm{c}$ \\
\hline Gourmet & Young-trimmed & 29.0 & $0.74 \mathrm{c}$ & $0.83 \mathrm{~d}$ \\
\hline Gourmet & Mature-trimmed & - & - & $1.39 \mathrm{a}$ \\
\hline Momotaro York & Untrimmed & 26.8 & $0.78 \mathrm{c}$ & $0.84 \mathrm{~d}$ \\
\hline Momotaro York & Young-trimmed & 26.6 & $1.24 \mathrm{a}$ & $1.29 \mathrm{~b}$ \\
\hline Momotaro York & Mature-trimmed & - & - & $1.44 \mathrm{a}$ \\
\hline \multirow[t]{3}{*}{ Significance $^{\mathrm{x}}$} & Cultivars & NS & 一 & - \\
\hline & Leaf trimming & NS & - & - \\
\hline & Interaction & NS & - & - \\
\hline
\end{tabular}
Dutch cultivar Gourmet and Japanese cultivar Momotaro York.

DAT $=$ days after transplanting.

${ }^{\mathrm{z}}$ Measured at $1000 \mu \mathrm{mol} \cdot \mathrm{mol}^{-1} \mathrm{CO}_{2}, 1500 \mu \mathrm{mol} \cdot \mathrm{mol}^{-1}$ photosynthetic photon flux density at 42 DAT. ${ }^{\mathrm{y}}$ Different letters indicate significant differences by $95 \%$ confidence intervals.

${ }^{\mathrm{x}} \mathrm{NS}$ indicates nonsignificant at $P<0.05$ by analysis of variance.

trimming treatments in either cultivar. There was no significant interaction of cultivars $x$ leaf trimming for leaf width. At both 56 and 71 DAT, untrimmed 'Momotaro York' leaves were significantly larger than those of 'Gourmet'. LAs also differed significantly by leaf trimming. At 71 DAT, LAs did not differ significantly between the untrimmed and young-trimmed leaves in either cultivar. However, mature-trimmed leaves were significantly smaller than untrimmed and youngtrimmed leaves in each cultivar.

There was no significant difference in the individual leaf photosynthetic rate between cultivars at 42 DAT (Table 2). There was also no significant difference between untrimmed and young-trimmed leaves at 42 DAT. The light-photosynthesis curves of the cultivars at 51 DAT were almost identical (Fig. 2). Accordingly, the leaf photosynthetic rate per unit area was equivalent between the cultivars.

LEC and DM production. At 63 and 72 DAT, the LEC of untrimmed 'Gourmet' was significantly higher than that of untrimmed plants in 'Momotaro York' (Table 2). Lightextinction coefficient of young-trimmed plants was significantly higher than that of untrimmed plants in 'Momotaro York' and lower than that of untrimmed plants in 'Gourmet' (Table 2). At 72 DAT, LEC of mature-trimmed leaves of both cultivars was

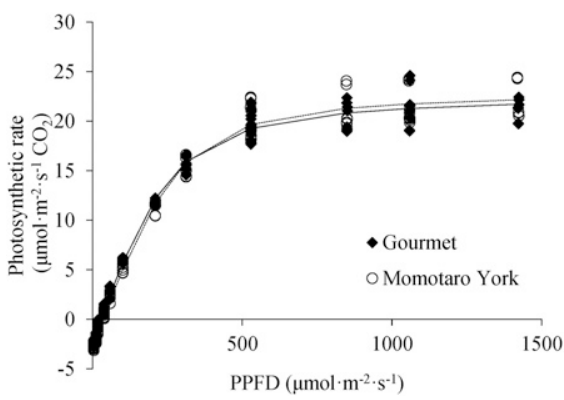

Fig. 2. Photosynthetic curves of individual leaves of Dutch cultivar Gourmet and Japanese cultivar Momotaro York at $51 \mathrm{~d}$ after transplanting. Photosynthetic rate $=\left\{\varphi I+P_{\mathrm{M}}-\left[\left(\varphi I+P_{\mathrm{M}}\right)^{2}-\right.\right.$ $\left.4 \varphi\left[\theta P_{\mathrm{M}}\right]^{0.5}\right\} / 2 \theta-R$, where $\varphi=$ initial slope, $I=$ light intensity, $P_{\mathrm{M}}=$ maximum photosynthetic rate, $\theta=$ degree of curvature, and $R=$ respiration rate. For 'Gourmet', $\varphi=0.087, P_{\mathrm{M}}=25.1$, $\theta=0.82$, and $R=2.36\left(R^{2}=0.99\right)$. For 'Momotaro York', $\varphi=0.081, P_{\mathrm{M}}=25.8, \theta=$ 0.86 , and $R=2.68\left(R^{2}=0.99\right)$.

significantly higher than those of untrimmed and young-trimmed plants. Because maturetrimming significantly decreased the individual LA of both cultivars (Table 1), both LAI and light interception decreased, so light interception decreased. On the other hand, by 71 DAT, there was no significant decrease 
in the individual LA because of youngtrimming (Table 1).

At 107 DAT, leaf trimming had no influence on internode length (8.1-8.4 and 8.1$8.2 \mathrm{~cm}$ in 'Gourmet' and 'Momotaro York', respectively) or number of leaves (34.7-34.9 and 32.5-33.1 leaves/plant in 'Gourmet 'and 'Momotaro York', respectively), i.e., leaf appearance. The LAI at 107 DAT differed significantly by leaf trimming in each cultivar (Table 3). In each trimming treatment, there was no significant difference in LAI between the cultivars. There was no significant difference in specific leaf area (SLA) and FW fruit yield among leaf trimming treatments. As for LAI, leaf DW differed significantly by leaf trimming. There was no significant difference in leaf DW between cultivars. The stem DW of 'Gourmet' was significantly greater than that of 'Momotaro York'. There was no significant difference in stem DW among treatments in each cultivar. There was no significant difference in fruit DW or TDM between cultivars or treatments. Although the DM allocation to fruits was lower in 'Gourmet' than in 'Momotaro York', there was no significant difference among treatments in each cultivar (0.51-0.55 and $0.57-0.58{\mathrm{~g} . \mathrm{g}^{-1}}^{\text {in }}$ 'Gourmet' and 'Momotaro York', respectively). The LUE of young-trimmed 'Gourmet' was significantly greater than that of 'Momotaro York' in young-trimmed treatments (Table 3). In 'Gourmet', there was no significant difference in LUE among treatments. In 'Momotaro York', however, LUE was significantly lower in young-trimmed plants than in untrimmed and mature-trimmed plants. There was no significant difference in LUE between untrimmed and mature-trimmed plants.

Leaf length was correlated significantly and positively with individual LA (Table 4). Individual LA was correlated significantly and positively with LAI and leaf DW. LAI was correlated significantly and positively with leaf DW. Accordingly, differences in leaf length due to leaf trimming and cultivar may be the main determinants of the differences in individual LA, leaf DW, and LAI. There was no significant correlation among the other components, including between TDM and LUE $(r=0.73, P=0.098)$.

\section{Discussion}

Effect of leaf trimming on LEC and LUE. To measure light interception by the crop canopy, Honjo and Shono (2001) measured leaf angle and distribution by image analysis. Shono and Sase (1996) measured leaf angle in different layers of the tomato canopy by 3D image measurement. However, the effect of leaf morphology on light interception by plants has not been reported. In 'Gourmet', there was no significant influence of leaf trimming on LUE (Table 3). In 'Momotaro York', however, although young-leaf trimming significantly increased the LEC (Table 2), it significantly decreased LUE (Table 3). LUE is determined mainly by individual leaf photosynthetic rate and the LEC (Higashide and Heuvelink, 2009). We found no significant difference in the maximum photosynthetic rate (Table 2) or in lightphotosynthesis curves between cultivars (Fig. 2) or between untrimmed and youngtrimmed plants (Table 2). Thus, the increase in the coefficient in 'Momotaro York' caused by young-leaf trimming might have contributed to the decrease in LUE, although there was no significant correlation between the two.

Mature-leaf trimming decreased both individual LA and LAI at 107 DAT (Tables 1 and 3). However, TDM and LUE were not influenced significantly (Table 3), possibly because of the short period (the experiment finished $34 \mathrm{~d}$ after the mature-leaf trimming) and the adequate LAI (3.49 in 'Gourmet' and 3.59 in 'Momotaro York'). Mature-leaf trimming significantly increased the LEC in each cultivar (Table 2). This increase in the LEC might be compensated by the decreases in individual LA and LAI. The increase in the coefficient may have increased light interception. Because mature-leaf trimming altered the leaf shape drastically (Fig. 1C), the increase in the coefficient might be caused by direct effects, indirect effects, or both of the leaf shape.

Differential effects of young-leaf trimming between cultivars. Although we did not measure the leaf angles, the angles in tomato canopies were measured in the preliminary experiment (T. Higashide, unpublished data). The leaf angles from horizontal plane at the base of the leaf were 2 to $18^{\circ}$ in 'Gourmet', and -9 to $18^{\circ}$ in 'Momotaro Fight', sister cultivar of 'Momotaro York'. The angles at the middle of the leaf in 'Gourmet' and 'Momotaro Fight' were -13 to $19^{\circ}$ and -39 to $70^{\circ}$, respectively. This shows that leaves rise upward at a greater angle in the Dutch cultivar than in the Japanese cultivar. Similarly, most Japanese cultivars have long downward-angled leaves but most Dutch cultivars have short upward-angled leaves (Nakano et al., 2012). We grew a long-leaf Japanese cultivar and a short-leaf Dutch cultivar (Table 1). Young-leaf trimming increased the LEC in 'Momotaro York' but decreased it in 'Gourmet' (Table 2), although there was no significant decrease in leaf length or individual LA (Table 1). There was also no significant difference in SLA or LAI (Table 3). Although young-leaf trimming did not decrease mature leaf length (Table 1), the trimming decreased the number of leaflets in the leaf. This leaflet and its weight decrease might influence leaf angle in expanding the leaf by reducing the weight of the leaf apex and by allowing the leaf to rise. The leaves of 'Momotaro York' hang roughly downward, and the trimming might make them more horizontal. Hence, the LEC

Table 3. Effects of leaf trimming on leaf area index (LAI), specific leaf area (SLA), fresh weight (FW) fruit yield, dry weights of leaves, stems, and fruits, total dry matter aboveground (TDM), and light-use efficiency in tomato Dutch cultivar Gourmet and Japanese cultivar Momotaro York at $107 \mathrm{~d}$ after transplanting.

\begin{tabular}{|c|c|c|c|c|c|c|c|c|c|}
\hline \multirow[b]{2}{*}{ Cultivar } & \multirow[b]{2}{*}{ Leaf trimming } & \multirow{2}{*}{$\begin{array}{c}\text { LAI } \\
\left(\mathrm{m}^{2} \cdot \mathrm{m}^{-2}\right)\end{array}$} & \multirow{2}{*}{$\begin{array}{c}\text { SLA } \\
\left(\mathrm{cm}^{2} \cdot \mathrm{g}^{-1}\right)\end{array}$} & \multirow{2}{*}{$\begin{array}{l}\text { FW fruit } \\
\text { yield } \\
\text { (kg/plant) }\end{array}$} & \multicolumn{3}{|c|}{$\begin{array}{c}\text { Dry wt } \\
\text { (g/plant) }\end{array}$} & \multirow{2}{*}{$\begin{array}{c}\text { TDM } \\
\left(\mathrm{g} \cdot \mathrm{m}^{-2}\right)\end{array}$} & \multirow{2}{*}{$\begin{array}{c}\mathrm{LUE} \\
\left(\mathrm{g} \cdot \mathrm{MJ}^{-1}\right. \\
P A R)\end{array}$} \\
\hline & & & & & leaves & stem & fruits $^{z}$ & & \\
\hline Gourmet & Untrimmed & 4.32 & 197 & 3.8 & 90 & 68 & 170 & 818 & $3.1 \mathrm{ab}^{\mathrm{y}}$ \\
\hline Gourmet & Young-trimmed & 3.66 & 188 & 4.0 & 79 & 63 & 174 & 788 & $3.3 \mathrm{a}$ \\
\hline Gourmet & Mature-trimmed & 3.49 & 191 & 3.6 & 72 & 62 & 157 & 756 & $3.2 \mathrm{abc}$ \\
\hline $\begin{array}{c}\text { Momotaro } \\
\text { York }\end{array}$ & Untrimmed & 4.61 & 209 & 4.2 & 89 & 45 & 176 & 767 & $2.9 \mathrm{~b}$ \\
\hline $\begin{array}{l}\text { Momotaro } \\
\text { York }\end{array}$ & Young-trimmed & 3.81 & 198 & 4.0 & 78 & 44 & 166 & 710 & $2.5 \mathrm{c}$ \\
\hline $\begin{array}{l}\text { Momotaro } \\
\text { York }\end{array}$ & Mature-trimmed & 3.59 & 206 & 4.3 & 71 & 44 & 177 & 761 & $2.8 \mathrm{~b}$ \\
\hline \multirow[t]{3}{*}{ Significance $^{\mathrm{x}}$} & Cultivar & NS & $* *$ & $* *$ & NS & $* * *$ & NS & NS & - \\
\hline & Leaf trimming & $* * *$ & NS & NS & $* * *$ & NS & NS & NS & - \\
\hline & Interaction & NS & NS & NS & NS & NS & NS & NS & - \\
\hline
\end{tabular}

${ }^{\mathrm{z}}$ Mature and immature fruits.

${ }^{\mathrm{y}}$ Values followed by different letters within a column differ significantly by $95 \%$ confidence intervals.

${ }^{\mathrm{x}} \mathrm{NS}, * *, * * *$ Nonsignificant or significant at $P<0.01$ or 0.001 , respectively, by analysis of variance $(n=$ 12).

Table 4. Correlation efficient $(R)$ between individual leaf and growth characteristics; leaf length, leaf width and area (LA), leaf area index (LAI), leaf dry weight (DW), total dry matter aboveground (TDM), light-extinction coefficient (LEC), and light-use efficiency (LUE) of a tomato Dutch cultivar Gourmet and Japanese cultivar Momotaro York that had trimmed and untrimmed leaves.

\begin{tabular}{|c|c|c|c|c|c|c|c|}
\hline & Leaf length & Leaf width & Individual LA & LAI & Leaf DW & TDM & LEC \\
\hline \multicolumn{8}{|l|}{ Leaf length } \\
\hline Leaf width & 0.37 & & & & & & \\
\hline Individual LA & $0.97 * *$ & 0.35 & & & & & \\
\hline LAI & 0.77 & 0.11 & $0.89^{*}$ & & & & \\
\hline Leaf DW & 0.75 & -0.18 & $0.83^{*}$ & $0.94 * *$ & & & \\
\hline TDM & -0.13 & -0.72 & -0.01 & 0.34 & 0.51 & & \\
\hline LEC & -0.65 & 0.22 & -0.64 & -0.62 & -0.74 & -0.48 & \\
\hline LUE & 0.42 & -0.77 & -0.36 & -0.11 & 0.07 & 0.73 & -0.41 \\
\hline
\end{tabular}

*,**Significant at $P<0.05$ or 0.01 , respectively. 
increased. On the other hand, because the leaves of 'Gourmet' face upward, trimming might cause them to rise further. Hence, the LEC decreased. To verify such a difference in the LEC due to young-leaf trimming, we need further investigations. However, the measurement of real plants has limitations such as leaf angle variations within a leaf and among the leaves, and continual measurement. To overcome these limitations, researchers have tried to model plant architecture using computer (Higashide, 2009; Sarlikioti et al., 2011; Watanabe et al., 2005). Andrieu et al. (1995) validated light interception by using a maize canopy in a 3D model. Percy and Yang (1996) and Takenaka et al. (1998) modeled the 3D architecture of plants from measurements of stem length and direction and of the arrangement of leaves and branches in space. Wiechers at al. (2011) successfully represented light distribution in a cucumber plant canopy and confirmed the model through individual-leaf light measurements. However, our experiment requires a 3D model to describe precise structure. Because plant morphology is sophisticated, it is not easy to describe the differences in appearance between leaf tip trimming. Such 3D models are insufficient to apply this analysis for now but could allow us to investigate individual leaf morphology and LECs.

For yield improvement by modification of leaf morphology. When LAI is high enough, a decrease in the LEC can increase LUE (Higashide and Heuvelink, 2009). We decreased the LEC in 'Gourmet' by trimming young leaves. Because such trimming is labor-intensive, it would be impractical for commercial cultivation, but leaf shape and light interception by plants could be improved by breeding. Recent molecular biological findings on lacinia formation and leaf shape of tomato plants show that some genes such as $K N O X$ and their proteins have important roles in the formation and development of leaflets (Blein et al., 2008; Jasinski et al., 2008; Kim et al., 2003; Shani et al., 2009; Shleizer-Burko et al., 2011). Plant hormones such as auxins and cytokines also have important roles through interactions with $K N O X$ genes (Ben-Gera et al., 2012; Burko et al., 2013; David-Schwartz et al., 2009). Moreover, tomato leaf shape is regulated by gene expression networks and the environment (Chitwood et al., 2014; Ichihashi et al., 2014). These findings might support the improvement of tomato cultivars in the near future. Our results suggest that if the number of leaflets of 'Gourmet' could be decreased, the LEC would decrease and LUE would improve, and thus fruit yield might improve. Decrease in LEC in several Dutch cultivars released in the past 50 years could contribute to an increase in LUE and yield (Higashide and Heuvelink, 2009). On the other hand, if the number of leaflets of 'Momotaro York' was decreased, the LEC could increase and LUE would not improve. In the previous report on Japanese cultivars, a yield improvement and a correlation of LUE and the light-extinction coefficient were not observed (Higashide et al., 2012).
We conclude that trimming young leaves might change the LEC without decreasing individual LA or LAI. Whether the coefficient increased or decreased would depend on the cultivar. Improvement in leaf shape and light interception by tomato plants would be useful for changing the LEC.

\section{Literature Cited}

Acock, B., D.A. Charles-Edwards, D.J. Fitter, D.W. Ludig, J. Warren Wilson, and A.C. Withers. 1978. The contribution of leaves from different levels within a tomato crop to canopy net photosynthesis: An experimental examination of two canopy models. J. Expt. Bot. 29:815-827.

Andrieu, B., N. Ivanov, and P. Boissard. 1995. Simulation of light interception from a maize canopy model constructed by stereo plotting. Agr. For. Meteorol. 75:103-119.

Ben-Gera, H., I. Shwartz, M. Shao, E. Shani, M. Estelle, and N. Ori. 2012. ENTIRE and GOBLET promote leaflet development in tomato by modulating auxin response. Plant J. 70:903-915.

Blein, T., A. Pulido, A. Vialette-Guiraud, K. Nikovics, H. Morin, A. Hay, I.E. Johansen, M. Tsiantis, and P. Laufs. 2008. A conserved molecular framework for compound leaf development. Science 322:1835-1839.

Burko, Y., S. Shleizer-Burko, O. Yanai, I. Shwartz, I. Daphne Zelnik, J. Jacob-Hirsch, I. Kela, L. Eshed-Williams, and N. Ori. 2013. A role for APETALA1/FRUITFULL transcription factors in tomato leaf development. Plant Cell 25:2070-2083.

Chitwood, D.H., A. Ranjan, R. Kumar, Y. Ichihashi, K. Zumstein, L.R. Headland, E. Ostria-Gallardo, J.A. Aguilar-Martínez, S. Bush, L. Carriedo, D. Fulop, C.C. Martinez, J. Peng, J.N. Maloof, and N.R. Sinha. 2014. Resolving distinct genetic regulators of tomato leaf shape within a heteroblastic and ontogenetic context. Plant Cell 26:3616-3629.

David-Schwartz, R., D. Koenig, and N.R. Sinha. 2009. LYRATE is a key regulator of leaflet initiation and lamina outgrowth in tomato. Plant Cell 21:3093-3104.

Goudriaan, J. 1988. The bare bones of leaf-angle distribution in radiation models for canopy photosynthesis and energy exchange. Agr. For. Meteorol. 43:155-169.

Higashide, T. 2009. Light interception by tomato plants (Solanum lycopersicum) grown on a sloped field. Agr. For. Meteorol. 149: 756-762.

Higashide, T. and E. Heuvelink. 2009. Physiological and morphological changes over the past 50 years in yield components in tomato. J. Amer. Soc. Hort. Sci. 134:460-465.

Higashide, T., A. Nakano, and K. Yasuba. 2014. Yield and dry matter production of a Japanese tomato cultivar are improved by grafting onto a Dutch rootstock 'Maxifort'. J. Jpn. Soc. Hort. Sci. 83:235-243.

Higashide, T., K. Yasuba, T. Kuroyanagi, and A. Nakano. 2015. Decreasing or non-decreasing allocation of dry matter to fruits in Japanese tomato cultivars in spite of the increase in total dry matter of plants by $\mathrm{CO}_{2}$ elevation and fogging. Hort. J. 84:111-121.

Higashide, T., K. Yasuba, K. Suzuki, A. Nakano, and H. Ohmori. 2012. Yield of Japanese tomato cultivars has been hampered by a breeding focus on flavor. HortScience 47:1408-1410.

Honjo, T. and H. Shono. 2001. Measurement of leaf tip angle by using image analysis and 3-D digitizer. J. Agr. Meteorol. 57:101-106. [in Japanese with English summary].

Ichihashi, Y., J.A. Aguilar-Martínez, M. Farhi, D.H. Chitwood, R. Kumar, L.V. Millon, J. Peng, J.N. Maloof, and N.R. Sinha. 2014. Evolutionary developmental transcriptomics reveals a gene network module regulating interspecific diversity in plant leaf shape. Proc. Natl. Acad. Sci. USA 111:E2616-E2621.

Iwakiri, S. and M. Inayama. 1974. Studies on the canopy photosynthesis of the horticultural crops in controlled environment (2) Distribution of percent sunlit leaf area in hedgerow cucumber canopies. J. Agr. Meteorol. 30:17-26. [in Japanese with English summary].

Jasinski, S., A. Tattersall, P. Piazza, A. Hay, J.F. Martinez-Garcia, G. Schmitz, K. Theres, S. McCormick, and M. Tsiantis. 2008. PROCERA encodes a DELLA protein that mediates control of dissected leaf form in tomato. Plant J. 56:603-612.

KIG (Kwantitatieve Informatie voor de Glastuinbouw). 2005. Proefstation voor de bloemistrij en glasgroente (PGB). Kwantitatieve Informatie voor de Glastuinbouw, Wageningen, the Netherlands.

Kim, M., T. Pham, A. Hamidi, S. McCormick, R.K. Kuzoff, and N. Sinha. 2003. Reduced leaf complexity in tomato wiry mutants suggests a role for PHAN and KNOX genes in generating compound leaves. Development 130:44054415.

Kuroyanagi, T., K. Yasuba, T. Higashide, Y. Iwasaki, and M. Takaichi. 2014. Efficiency of carbon dioxide enrichment in an unventilated greenhouse. Biosyst. Eng. 119:58-68.

Li, T., E. Heuvelink, T.A. Dueck, J. Janse, G. Gort, and L.F.M. Marcelis. 2014. Enhancement of crop photosynthesis by diffuse light: Quantifying the contributing factors. Ann. Bot. 114:145156.

Li, T. and Q. Yang. 2015. Diffusing the incident light: A potential measure for improving greenhouse production, p. 25-36. In: T. Higashide (ed.). Solanum lycopersicum. Nova Publ., New York, NY.

Monsi, M. and T. Saeki. 2005. On the factor light in plant communities and its importance for matter production. (Über den Lichtfaktor in den Pflanzengesellschaften und seine Bedeutung für die Stoffproduktion Jpn. J. Bot. 14:2252). Ann. Bot. 95:549-567.

Nakano, A., K. Yasuba, and T. Higashide. 2012. Morphological characteristics of Dutch and Japanese cultivar and its relationship to high yield. Agr. Hort. 87:993-997. [in Japanese].

Papadopoulos, A.P. and S. Pararajasingham. 1997. The influence of plant spacing on light interception and use in greenhouse tomato ( $\mathrm{Lyco}$ persicon esculentum Mill): A review. Sci. Hort. 69:1-29.

Percy, R.W. and W. Yang. 1996. A threedimensional crown architecture model for assessment of light capture and carbon gain by understory plants. Oecologia 108:1-12.

Sarlikioti, V., P.H. de Visser, and L.F.M. Marcelis. 2011. Exploring the spatial distribution of light interception and photosynthesis of canopies by means of a functional-structural plant model. Ann. Bot. 107:875-883.

Shani, E., Y. Burko, L. Ben-Yaakov, Y. Berger, Z. Amsellem, A. Goldshmidt, E. Sharon, and N. Ori. 2009. Stage-specific regulation of Solanum lycopersicum leaf maturation by class 1 KNOTTED1-LIKE HOMEOBOX proteins. Plant Cell 21:3078-3092.

Shleizer-Burko, S., Y. Burko, O. Ben-Herzel, and N. Ori. 2011. Dynamic growth program regulated 
by LANCEOLATE enables flexible leaf patterning. Development 138:695-704.

Shono, H. and S. Sase. 1996. Three dimensional image measurement of leaf tip angle and outline of shape of tomato plants. Envrion. Control Biol. 34:75-85. [in Japanese with English summary].

Takenaka, A., Y. Inui, and A. Osawa. 1998. Measurement of three-dimensional structure of plants with simple device and estimation of light capture of individual leaves. Funct. Ecol. 12:158-165.

Thornley, J.H.M. 1976. Photosynthesis, p. 92110. In: J.H.M. Thornley (ed.). Mathematical models in plant physiology. Academic Press, London, UK.

Watanabe, T., J.S. Hanan, P.M. Room, T. Hasegawa, H. Nakagawa, and W. Takahashi. 2005. Rice morphogenesis and plant architecture: Measurement, specification and the reconstruction of structural development by 3D architectural modeling. Ann. Bot. 95:1131-1143.

Wiechers, D., K. Kahlen, and H. Stützel. 2011. Evaluation of a radiosity based light model for greenhouse cucumber canopies. Agr. For. Meteorol. 151:906-915.
Yasuba, K., T. Hoshi, S. Kaneko, T. Higashide, H. Omori, and A. Nakano. 2013. Establishment of an environmental measurement node using open source hardware. Agric. Inform. Res. 22:247255. [in Japanese with English summary].

Yasuba, K., K. Suzuki, H. Sasaki, T. Higashide, and M. Takaichi. 2011. Fruit yield and environmental condition under integrative environment control for high yielding production at long-time culture of tomato. Bull. Natl. Inst. Veg. Tea Sci. 10:85-93. [in Japanese with English summary] 